INTERNATIONAL JOURNAL OF RESEARCHES IN BIOSCIENCES, AGRICULTURE AND TECHNOLOGY

(C) VISHWASHANTI MULTIPURPOSE SOCIETY (Global Peace Multipurpose Society) R. No. MH-659/13(N) www.vmsindia.org

\title{
SOME STUDIES ON WASTE WATER IRRIGATION WITH RESPECT TO HEAVY METALS
}

\author{
C. B. Meshram ${ }^{1}$, Pramod Meshram² and Pradnya Meshram ${ }^{3}$ \\ 1P.G. Deptt. of Zoology, Shri. Shivaji Science College, Amravati \\ 2,3Research Student Shri. Shivaji Science College, Amravati
}

\begin{abstract}
:
Vegetables are important ingredients of human diets, that contains essential nutrients and trace elements. For the development of human life heavy metals are essential. Contaminated vegetables may produce health effects on human life due to excess of heavy metals. Propose study investigate the level of six different heavy metals which are toxic $(\mathrm{Cr}, \mathrm{Cd}, \mathrm{Ni}, \mathrm{Fe}, \mathrm{Zn}, \mathrm{Cu})$ in different vegetables irrigated from waste water of Amba Nala flowing through Amravati metro city of Maharashtra state, India. Heavy metals were extracted by extraction method using concentrated $\mathrm{HNO}_{3}$, atomic adsorption spectrophotometer were used to analyze the level of heavy metals. Heavy metals were evaluated from waste water and from selected seasonal vegetables. The contents of heavy metals in waste water were found very high than vegetables crossing the permissible limit. Seasonal variation in heavy metals are also discussed.
\end{abstract}

Keywords - Heavy Metals, Waste Water, Vegetables.

\section{Introduction:}

Waste water irrigation resulted in the significant mixing of heavy metals contents of agricultural land (Mapanda et.al 2005). Thus long term waste water irrigation leads to build up of heavy metals in soil and food crop (Khan et.al 2008). The polluted effluents water is found to be reach not only in organic water and nutrients but also heavy metals like $\mathrm{Cd}, \mathrm{Cr}, \mathrm{Fe}$, $\mathrm{Ni}, \mathrm{Zn}$, and $\mathrm{Cu}$ etc. that finally reach to soil through irrigation and leads to food chain contamination as crop and vegetables absorb them from the soil. Heavy metals are not easily biodegradable and leads to their accumulation in human vital organs causing various diseases, (Ward et.al 1995). The use of domestic waste water for irrigation practice is common on Amba Nala in adjoining villages of Amravati. Therefore an attempt has been made to focus sever pollution problem of soil and water quality in vegetables. Some vegetables like tomato, brinjal, cabbage \& spinach are tested for their toxicity in relation to human health.

\section{Materials and Methods:}

In the present study heavy metals in vegetables like tomato, brinjal, cabbage and spinach are analyzed, similarly waste water sample used for irrigation are tested for their qualitative and quantitative estimation.

\section{Wastewater and vegetables Sampling -}

100 gm of edible and leafy parts of different vegetables are collected from the field of sampling sites. Small pieces of sample are dried, grinded, and mix homogenously. $1 \mathrm{gm}$ of sample weighing on electronic balance are keep in small beaker by adding $5 \mathrm{ml}$ of concentrated $\mathrm{HNO}_{3}$ for overnight, then properly digested sample was evaluated on AAS. Similarly waste water sample are also digested and evaluated for their toxicity.

\section{Result and Discussion:}

Metallic elements are ubiquitous in the environment. Some trace elements are significant in nutrition, either for their essential nature or their toxicity. In the present studies quantitative analysis of heavy metals in wastewater and in vegetables on seasonal basis are shown in table- $1 \& 2$ (Fig-1\&2) for rainy season and winter season respectively.

Heavy metal concentration found higher in sewage water this is in agreement with Rattan et al (2005). However, seasonal trend showed lower concentration of heavy metal during rainy days as compared to winter. It may be due to dilution effect. Waste water used for irrigation showed higher concentration in both the season when compared with standard values, FAO, 1985. Heavy metal concentration varied among different vegetables (Fig1\&2) which may be attributed to variation in heavy metal concentration (Vousta et al,1996). In the present investigation concentration of metals were compared with permissible limits of Indian Standard (Awasthi,2000) and safe limits given by WHO/FAO, (2007). It was found that concentration were higher in all the studied vegetables.

It has been studied that higher concentration of copper toxicity above the safe level reveals the vegetables are contaminated with copper and are toxic to consumer (Xiong and Wang,2005; Anuja Asdeo and Sangeeta Loonker,2011). Concentration of $\mathrm{Cu}$ was found in order Spinach $>$ Brinjal $>$ Cabbage $>$ Tomato for rainy season (Table-1) and Spinach $>$ Tomato $>$ Cabbage $>$ Brinjal during winter months.

Zinc accumulation was found to maximum crossed standard and safe limit WHO/FAO and FAO. Maximum level of tolerance of zinc for human health is $20 \mathrm{mg} / \mathrm{kg}$ according to Chinese Department of preventive Medicine (1995). Acute exposure of zinc can cause tachycardia, 
vascular shock, dyspeptic nausea, vomiting, pancreatic disorder, diarrhea and damage of hepatic parenchyma (Salqueiro et al,2000).

As the level of cadmium exceed the limit prescribed by FAO and WHO/FAO, consumer must be prevented from their use.

Table - $1 \& 2$ gives the comparative concentration of iron uptake in vegetable matter is many fold higher than standard values. Concentration potential was maximum except cabbage $(0.699 \mathrm{mg} / \mathrm{gm})$.

Level of nickel and chromium during rainy season was observed within permissible limit except spinach $0.41 \mathrm{mg} / \mathrm{Gm}$. However, the results in winter months was found higher than standard values and safe limit. The concentration of different metals in vegetable samples has been compared with natural concentration and Indian standard in Table $1 \& 2$, Fig 1\&2. It was seen that level of each

Table No. 1 - Quantitative analysis of heavy metal in waste water and in vegetables during rainy season.

\begin{tabular}{|l|l|l|l|l|l|l|l|}
\hline $\begin{array}{l}\text { Sr. } \\
\text { No. }\end{array}$ & $\begin{array}{l}\text { Elements } \\
\mathrm{mg} / 1\end{array}$ & $\begin{array}{l}\text { Standard } \\
\text { values }\end{array}$ & $\begin{array}{l}\text { Waste } \\
\text { water value } \\
\mathrm{mg} / 1\end{array}$ & Tomato & Brinjal & Cabbage & Spinach \\
\hline 1 & $\mathrm{Cu}$ & 0.05 & 3.085 & 0.122 & 0.651 & 0.611 & 1.712 \\
\hline 2 & $\mathrm{Fe}$ & 0.1 & 2.512 & 1.225 & 1.266 & 0.699 & 2.094 \\
\hline 3 & $\mathrm{Cd}$ & 0.01 & 1.395 & 0.025 & 0.072 & 0.044 & 0.091 \\
\hline 4 & $\mathrm{Cr}$ & 0.05 & 0.013 & 0.013 & 0.032 & 0.019 & 0.41 \\
\hline 5 & $\mathrm{Zn}$ & 5.00 & 1.924 & 1.02 & 1.098 & 0.756 & 1.624 \\
\hline 6 & $\mathrm{Ni}$ & 0.75 & 0.571 & 0.11 & 0.011 & 0.075 & 0.019 \\
\hline
\end{tabular}

Table No. 2 - Quantitative analysis of heavy metal in waste water and in vegetables during winter season.

\begin{tabular}{|l|l|l|l|l|l|l|l|}
\hline $\begin{array}{l}\text { Sr. } \\
\text { No. }\end{array}$ & $\begin{array}{l}\text { Elements } \\
\mathrm{mg} / \mathrm{l}\end{array}$ & $\begin{array}{l}\text { Standard } \\
\text { values }\end{array}$ & $\begin{array}{l}\text { Waste } \\
\text { water value } \\
\mathrm{mg} / 1\end{array}$ & Tomato & Brinjal & Cabbage & Spinach \\
\hline 1 & $\mathrm{Cu}$ & 0.05 & 6.243 & 2.01 & 1.851 & 1.990 & 2.01 \\
\hline 2 & $\mathrm{Fe}$ & 0.1 & 6.173 & 1.275 & 1.266 & 1.06 & 1.07 \\
\hline 3 & $\mathrm{Cd}$ & 0.01 & 2.016 & 0.999 & 0.786 & 0.751 & 0.780 \\
\hline 4 & $\mathrm{Cr}$ & 0.05 & 0.897 & 0.872 & 0.210 & 0.220 & 0.75 \\
\hline 5 & $\mathrm{Zn}$ & 5.00 & 7.266 & 3.220 & 2.280 & 3.02 & 4.02 \\
\hline 6 & $\mathrm{Ni}$ & 0.75 & 1.433 & 1.001 & 1.05 & 1.07 & 1.75 \\
\hline
\end{tabular}

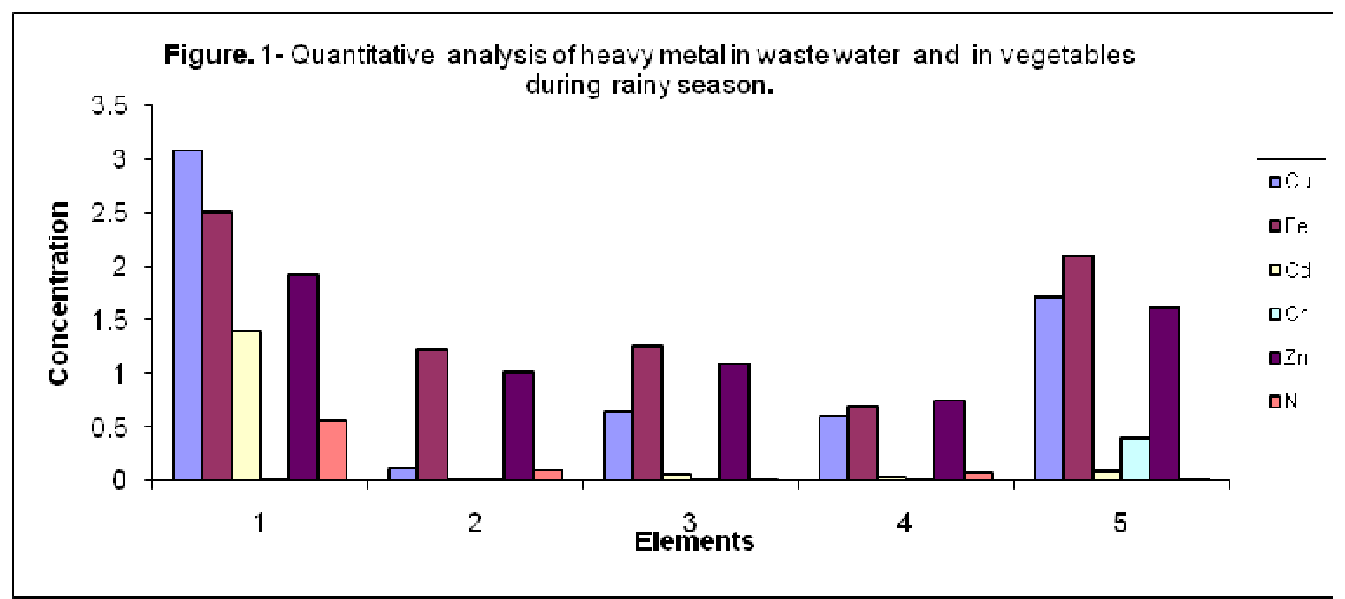

metals in vegetables were many folds higher than the natural concentration and Indian standards. Overall observations on coparision showed that metals in irrigation water cause vegetables should not be consumed at all.

\section{Conclusion :}

Heavy metal shows toxic potential which causes adverse effect on human health. Hence it has made attention of scientist and common pe towards the harmful effect of metals. Thus regular monitoring of heavy metal contamination in vegetables grown at waste water irrigated area is necessary and consumption of contaminated vegetables should be avoided in order to reduce the health risk. The waste water treatment technology should involve step to remove heavy metals causing risk to human health. severe impact on vegetable produce and such 


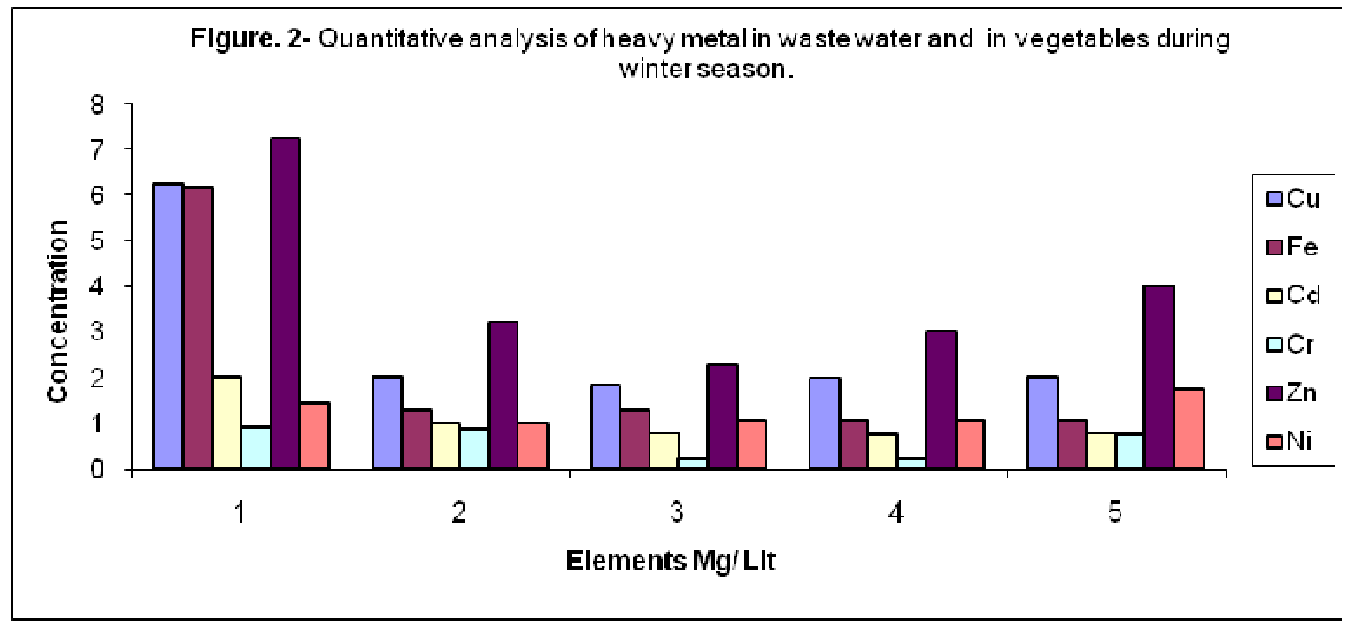

\section{References :}

1. Anjuja Asdev and Sangeeta Loonker (2011) : A Comparative analysis of Trace metal in vegetable, Toxicology, 5;125-132.

2. Awasthi, S. K. (2000) : prevention of food Adulteration act no. 37 of 1954, central and state rule as Amended for 1999 Ashoka Law house, New Delhi.

3. FAO 1985 Water quality for Agriculture. Paper no. 29 (Rev-1) UNESCO, Publication Rome.

4. Khan S. A.,Lin, S.Zhang, Q. Huc andY. Zhu , 2008 accumulation of polycyclic aromatic Hydrocarbons and heavy metal in Lettuce grown in the soil contaminated with long term waste water irrigation, Journal of Hazardous material 152; 506-515.

5. Mapanda, F, Mangwayana, E. N., Nyamangra J. and Giller K.E. (2005). The effect of long term irrigation using water on heavy metals contents of soil under vegetable, agriculture, ecosystem and environment 107, 151-156.

6. Rattan,R.K, S.P.Dutta,P.K.Chhonkar,K. Suribabu and A.K.Sing (2005) : Long term impact of irrigation with sewage effluent on heavy metal content in soil crop and ground water : A case study. Agriculture ecosystem and environment 109 : 310-322.

7. Salqueiro, M .J; et al (2000): Zinc is an essential micronutrient : A review, Nutr. Res, 20 : 737 -755.

8. Vousta,D.A; Grimanis and C.Samera (1996): Trace element in vegetable grown in an industrial area in relation to soil and air particulate matter. Environmental Pollution, 94:325-355.

9. Ward, N.I; F.W.Field and P.J. Haines (1995) : Environmental Analytical Chemistry : in Trace element. Nackie Academic and professional, U.K. pp- 320-328.

10. WHO/FAO (2007) : Food standard Program me Codex Alimentarius Commission 13 Session Report, Houstan United State of America, ALINORM 07/30/13.

11. Xiong, Z.T and H.Wang (2005) : Copper toxicity and bioaccumulation in Chinese cabbage. (Brassica pekinensis Rupr.). Environ. Toxicol, $20: 18$ 